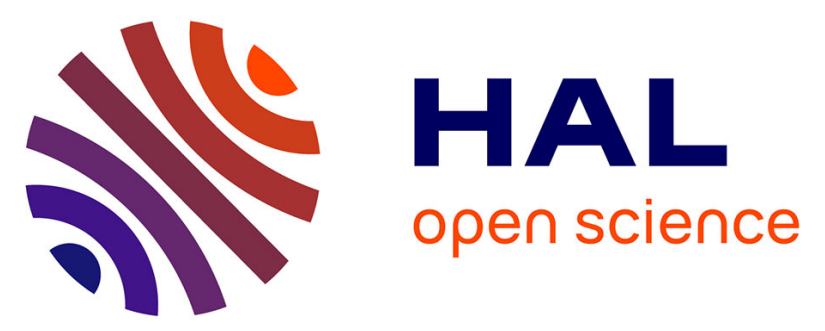

\title{
Two hundred years of land-use change in the South Swedish Uplands : comparison of historical map-based estimates with a pollen-based reconstruction using the landscape reconstruction algorithm
}

Florence Mazier, Anna Brostrom, P Bragée, Daniel Fredh, Li Stenberg, Géraldine Thiere, S. Sugita, D. Hammarlund

\section{To cite this version:}

Florence Mazier, Anna Brostrom, P Bragée, Daniel Fredh, Li Stenberg, et al.. Two hundred years of land-use change in the South Swedish Uplands: comparison of historical map-based estimates with a pollen-based reconstruction using the landscape reconstruction algorithm. Vegetation History and Archaeobotany, 2015, 24, pp.1-16. hal-01171964

\author{
HAL Id: hal-01171964 \\ https://hal.science/hal-01171964
}

Submitted on 6 Jul 2015

HAL is a multi-disciplinary open access archive for the deposit and dissemination of scientific research documents, whether they are published or not. The documents may come from teaching and research institutions in France or abroad, or from public or private research centers.
L'archive ouverte pluridisciplinaire HAL, est destinée au dépôt et à la diffusion de documents scientifiques de niveau recherche, publiés ou non, émanant des établissements d'enseignement et de recherche français ou étrangers, des laboratoires publics ou privés. 


\title{
Two hundred years of land-use change in the South Swedish Uplands: comparison of historical map-based estimates with a pollen-based reconstruction using the landscape reconstruction algorithm
}

\author{
Florence Mazier • Anna Broström • Pétra Bragée • \\ Daniel Fredh $\cdot$ Li Stenberg • Géraldine Thiere • \\ Shinya Sugita $\cdot$ Dan Hammarlund
}

Received: 17 November 2014/ Accepted: 25 January 2015

(C) Springer-Verlag Berlin Heidelberg 2015

\begin{abstract}
Long-term records of environmental history at decadal to millennial time-scales enable an assessment of ecosystem variability and responses to past anthropogenic disturbances and are fundamental for the development of environmental management strategies. This study examines the local variability of land-use history in the South Swedish Uplands over the last 200 years based on pollen records from three lake-sediment successions. Temporal changes in the proportional cover of 14 plant taxa were quantified as percentages using the landscape reconstruction algorithm (LRA). The LRA-based estimates of the extent of four landuse categories (cropland, meadows/grassland, wetland,
\end{abstract}

Communicated by F. Bittmann.

Electronic supplementary material The online version of this article (doi:10.1007/s00334-015-0516-0) contains supplementary material, which is available to authorized users.

\section{F. Mazier $(\bowtie)$}

CNRS GEODE UMR 5602, Jean Jaurès University, Toulouse,

France

e-mail: florencemazier@yahoo.fr

F. Mazier · A. Broström · P. Bragée · D. Fredh · L. Stenberg ·

D. Hammarlund

Department of Geology, Lund University, Lund, Sweden

A. Broström

Swedish National Heritage Board, Lund, Sweden

L. Stenberg

WSP Environmental, Helsingborg, Sweden

G. Thiere

Lund municipality, Lund, Sweden

S. Sugita

Institute of Ecology, Tallinn University, Tallinn, Estonia outland/woodland) were compared to corresponding estimates based on historical maps and aerial photographs from AD 1769-1823, 1837-1895, 1946 and 2005. Although the LRA approach tends to overestimate grassland cover by 10-30\% for the two earliest time periods, the reconstructed vegetation composition is generally in good agreement with estimates based on the historical records. Subsequently, the LRA approach was used to reconstruct the 200-year history of local land-use dynamics at 20-year intervals around two small lakes. The qualitative assessment of difference approach, which requires fewer assumptions and parameters than LRA for objective evaluation of between-site differences in plant abundances, provides consistent results in general. Significant differences exist in the land-use history between the sites. Local catchment characteristics, such as soil conditions and wetland cover, appear important for the development of human impact on the landscape. Quantifications of past vegetation dynamics provide information on the amplitude, frequency and duration of the land-use changes and their effects on terrestrial and aquatic ecosystems, and should be taken into account when nature conservation strategies are developed.

Keywords Lake sediments - Pollen analysis - Landscape reconstruction algorithm · Land-use cover · Istorical maps

\section{Introduction}

Understanding the effects of land-use changes on terrestrial and aquatic ecosystems is fundamental for the development of environmental management strategies. Long-term records of environmental history at decadal to millennial time-scales enable an assessment of ecosystem variability and responses to past anthropogenic disturbances (Willis 
and Birks 2006). Lake sediments offer a multitude of ecological, physical and chemical proxies for the reconstruction of past environmental changes in lakes and their surrounding landscapes in response to human impact (Willis and Birks 2006; Renberg et al. 2009).

Pollen records provide proxy time-series of past vegetation changes, and hence valuable long-term perspectives on the dynamics of contemporary ecological systems beyond the reach of historical data. Pollen records, however, are difficult to use for quantitative reconstructions of past vegetation at clearly defined spatial scales (Anderson et al. 2006). Several aspects of the pollenvegetation relationship have been poorly constrained, such as inter-taxonomic differences in pollen productivity and dispersal, and the spatial structure of the surrounding vegetation. Over the last decades, advances in the theory of pollen analysis (Prentice 1985, 1988; Sugita 1993) have helped overcome some of these fundamental issues. Sugita (2007a, b) introduced the landscape reconstruction algorithm (LRA) - a theory-based approach for quantitative reconstruction of vegetation and land cover. This approach consists of two steps, first it uses the REVEALS model (Regional Estimates of VEgetation Abundance from Large Sites) for a reconstruction of the regional vegetation composition within $50-100 \mathrm{~km}$ radii using pollen records from large sites (>100-500 ha), and secondly it uses the LOVE model (LOcal Vegetation Estimates) for a reconstruction of the vegetation composition within the relevant source area of pollen (RSAP; Sugita 1994) at smaller-sized sites in the same region. Although the REVEALS model has been frequently tested and applied in Europe (Hellman et al. 2008a, b; Sugita et al. 2008; Soepboer et al. 2010; Fredh et al. 2012, 2013; Nielsen et al. 2012), the entire LRA process has been tested empirically in only a few studies (Nielsen and Odgaard 2010; Sugita et al. 2010; Overballe-Petersen et al. 2012; Cui 2013; Cui et al. 2014).

In the present study we apply the LRA approach to reconstruct vegetation and land-use dynamics in southern Sweden. We use pollen records from three nearby lakes for the reconstruction of vegetation and land-use history since $\mathrm{AD}$ 1800. These lakes are situated in a typical rural landscape setting, where historical maps are available from $\mathrm{AD}$ 1769. The aims of this study are to evaluate the performance of the LRA approach by comparing the LRA-based estimates with land-use cover derived from several historical maps and aerial photographs and to fill the gaps in information on land-use changes over the past 200 years between the mapped periods. Because the number of lake sites is limited and not ideal for the LRA application, we evaluate also the validity of the approach and results using the qualitative assessment of difference (QAD) method (Sugita et al. 2006); QAD requires much fewer assumptions and parameters to evaluate objectively between-site differences in plant abundance and thus is appropriate considering the data sets we have, even though results are qualitative.

Hereafter, if not stated otherwise, all dates are given in calibrated radiocarbon years AD throughout this article.

\section{Study sites}

The study area is located in the province of Småland-the uplands of southern Sweden (Fig. 1). The crystalline bedrock, dominated by granite and gneiss (Wikman 2000), is covered by sandy till and scattered peat deposits (Daniel 2009). The climate is generally maritime with a mean annual temperature of $6.4{ }^{\circ} \mathrm{C}$ and an annual precipitation of $651 \mathrm{~mm}$ (Alexandersson et al. 1991). The regional vegetation belongs to the boreo-nemoral zone characterized by mixed coniferous and deciduous woodland (Sjörs 1963; Gustafsson and Ahlén 1996). Three lakes were selected for this study: Fiolen $\left(57^{\circ} 04^{\prime} 56^{\prime \prime} \mathrm{N}, 14^{\circ} 31^{\prime} 49^{\prime \prime} \mathrm{E}\right.$; 160 ha), Åbodasjön $\left(57^{\circ} 05^{\prime} 08^{\prime \prime} \mathrm{N}, 14^{\circ} 28^{\prime} 57^{\prime \prime} \mathrm{E} ; 50 \mathrm{ha}\right)$ and Lindhultsgöl $\left(57^{\circ} 08^{\prime} 42^{\prime \prime} \mathrm{N}, 14^{\circ} 28^{\prime} 04^{\prime \prime} \mathrm{E} ; 7\right.$ ha) (Fig. 1), with the latter two sites used for reconstructing local-scale changes in vegetation and land-use. Åbodasjön is an oligotrophic mesohumic lake currently surrounded by managed conifer-dominated woodland with semi-open areas of broadleaved trees and cropland near its margins. Lindhultsgöl is an oligotrophic polyhumic lake with a catchment mostly occupied by managed coniferous woodland and peatland (Fig. 1).

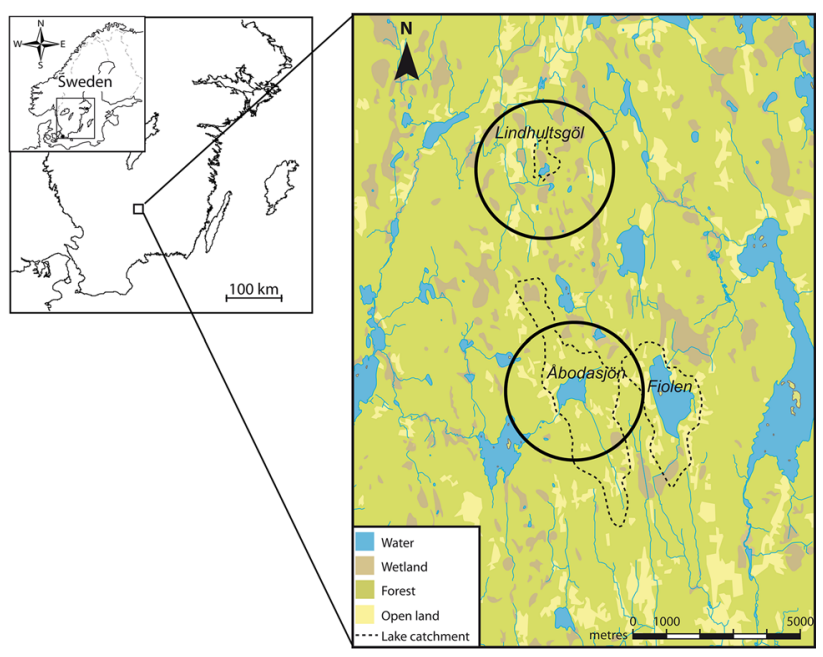

Fig. 1 Locations of lakes Fiolen, Åbodasjön and Lindhultsgöl in the South Swedish Uplands. $2 \mathrm{~km}$ radii (approximate spatial scale of the LRA reconstruction) within which historical maps were surveyed (black circles) are shown in the perspective of modern land use. The catchments of the respective lakes are shown by dashed lines 
Historical maps of land-use changes in the vicinity of the lakes

Different formats of land-use maps have been produced in Sweden since the 18 th century. From 1749 , cadastral maps were produced to reduce the fragmentation of land patches owned by individual farmers for increased agricultural efficiency and productivity (Örback 1998). From 1939 to 1976 the national government replaced the traditional mapping methods with economic maps based on aerial photographs for administrative purposes, including forest and agriculture management. Around Åbodasjön and Lindhultsgöl cadastral maps are available from the storskifte reform in 1769-1826 and the laga skifte reform in 1837-1895. Economic maps were produced in 1946 (ESM) and we used an additional set of rectified aerial photographs (orthophotos) from 2005. These local-scale historical records provide spatial information on the past distribution of different land-use categories, such as wetland, cropland, outland/woodland and meadows/grassland during specific time periods, although species composition specific to individual land-use categories cannot be determined (Dahlström 2008). The meadows are classified as those primarily used for hay production from non-fertilized and naturally grown grasses. The outland was the common land of a village, used for cattle grazing, collection of firewood and timber production. During the laga skifte reform the common land disappeared as it was divided among the farms in the village.

Around Åbodasjön and Lindhultsgöl, 12 and 10 storskifte reform maps, respectively, are available from the early 1800 s, with two types of map for each village, one covering the inland (cropland and meadow) closest to the village owned by the individual farmers and the other covering the outland; land owned commonly by all farmers in each village. From the late 1800s, ten and twelve laga skifte reform maps are available respectively, with one map for each village, covering both the inland and outland. Six economic maps from 1946 and one orthophoto from 2005 cover the entire study area.

\section{Methods}

Field work

Surface sediment sequences were collected in 2008, using a gravity corer (Renberg and Hansson 2008), yielding the uppermost $32 \mathrm{~cm}$ at Åbodasjön (8.6 m water depth), $30 \mathrm{~cm}$ at Lindhultsgöl $(5.2 \mathrm{~m})$, and $44 \mathrm{~cm}$ at Fiolen $(6.8 \mathrm{~m})$. Longer, over-lapping sediment sequences were collected at the same locations and depths at the individual sites, using Russian and piston corers, yielding $4.5 \mathrm{~m}$ sediment at Åbodasjön, $2.6 \mathrm{~m}$ at Lindhultsgöl and $5.7 \mathrm{~m}$ at Fiolen.
Correlation and chronology

At each site, correlations between the long cores and the surface sediment sequences were established by mineral magnetic properties (Thompson et al. 1980) and X-ray fluorescence (XRF) measurements of element concentrations (Boyle 2000).

This study is based on the most recent 200-year parts of the records (Fig. 2), which in total cover ca. 1,000 years at Åbodasjön, ca. 2,600 years at Lindhultsgöl and ca. 2,600 years at Fiolen. The age-depth models as published in Fredh et al. (2013) and Bragée et al. (2013a) were based on combinations of ${ }^{210} \mathrm{~Pb}$ (constant rate of supply modelling), ${ }^{14} \mathrm{C}$ of terrestrial plant remains and $\mathrm{Pb}$ pollution markers using Bayesian analysis. The chronology for Åbodasjön (covering the uppermost $130 \mathrm{~cm}$ ) was based on $25{ }^{210} \mathrm{~Pb}$ analyses, three ${ }^{14} \mathrm{C}$ macrofossil dates and four $\mathrm{Pb}$ pollution age markers. The chronology for Lindhultsgöl $(80 \mathrm{~cm})$ was based on $19{ }^{210} \mathrm{~Pb}$ analyses, two ${ }^{14} \mathrm{C}$ macrofossil dates and five $\mathrm{Pb}$ pollution age markers, and the chronology for Fiolen

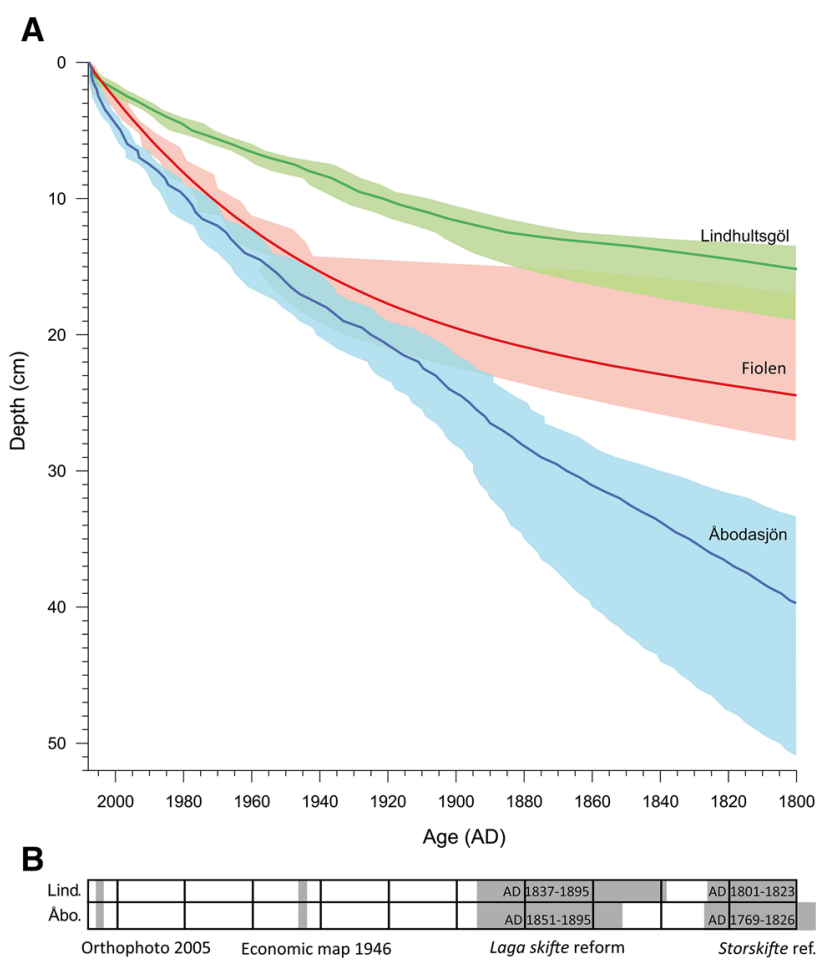

Fig. 2 a Age-depth models for the sediment records from Lindhultsgöl (green line), Fiolen (red line), and Åbodasjön (blue line) across the 200-year study period. Below the reach of reliable ${ }^{210} \mathrm{~Pb}$ profiles the age models were constrained by radiocarbon dates and lead pollution marker horizons. The shading indicates uncertainty envelopes with double standard deviations; b Overview of the 20 year pollen-count intervals together with the time spans of compiled and digitalized historical maps within $2 \mathrm{~km}$ radii around Lindhultsgöl and Åbodasjön 
$(160 \mathrm{~cm})$ was based on nine ${ }^{210} \mathrm{~Pb}$ analyses, six ${ }^{14} \mathrm{C}$ macrofossil dates and four $\mathrm{Pb}$ pollution age markers.

Pollen analysis

Sediment samples, $1 \mathrm{~cm}^{3}$, were collected at $0.5 \mathrm{~cm}$ intervals and treated by the acetolysis method (Berglund and Ralska-Jasiewiczowa 1986). The pollen grains were counted and identified for each level using identification keys (Punt et al. 1976-2009; Beug 2004) and the reference collection at the Department of Geology, Lund University. Pollen counts from several levels were pooled together to attain at least 1,000 pollen grains of arboreal and nonarboreal types, as shown in Table 1, for each 20-year time window (Fig. 2).
Pollen-based reconstruction of vegetation and land-use

This study is based on pollen records from Fiolen, Åbodasjön and Lindhultsgöl (Fig. 1) for reconstructing local vegetation and land-use using the LRA approach (Sugita 2007a, b; Sugita et al. 2010). For a reliable reconstruction of regional vegetation using REVEALS - the first step of the LRA - pollen records from a few lakes $>100-500$ ha would be ideal (Sugita 2007a; Hellman et al. 2008a; Sugita et al. 2010). However, pollen data are available for this project from only three differently-sized lakes in the range of 7-160 ha. Extensive simulations (Sugita 2007a) and empirical evidence (Hellman et al. 2008a; Mazier et al. 2012) suggests that pollen records from multiple sites increase the reliability of the REVEALS estimates, even

Table 1 Relative pollen productivity and fall speed of pollen of taxa and groups of taxa included in the landscape reconstruction algorithm analysis

\begin{tabular}{|c|c|c|c|c|c|}
\hline $\begin{array}{l}\text { Taxa/groups of taxa included } \\
\text { in the LRA reconstruction }\end{array}$ & Taxa included in groups & $\begin{array}{l}\varnothing \text { of pollen } \\
\text { grains }(\mu \mathrm{m})\end{array}$ & $\begin{array}{l}\text { Fall speed } \\
\left(\mathrm{m} \mathrm{s}^{-1}\right)\end{array}$ & PPE & SE \\
\hline Alnus & & & 0.021 & 4.200 & 0.140 \\
\hline Betula & & & 0.024 & 8.867 & 0.134 \\
\hline Calluna vulgaris & & & 0.038 & 1.102 & 0.054 \\
\hline \multirow[t]{5}{*}{ Car.Fra.Til.Ulm } & & 34.7 & 0.034 & 1.317 & 0.024 \\
\hline & Carpinus & $42.6^{\mathrm{a}}$ & & & \\
\hline & Fraxinus & $23.7^{\mathrm{a}}$ & & & \\
\hline & Tilia (T. platyphyllos, T. cordata) & $35.9^{\mathrm{a}}$ & & & \\
\hline & Ulmus (U. glabra, U. laevis, $U$. minor $)$ & $36.7^{\mathrm{a}}$ & & & \\
\hline \multirow[t]{3}{*}{ Cereals (sums) } & & 52.4 & 0.078 & 1.882 & 0.033 \\
\hline & Cerealia-type & $53.3^{\mathrm{a}}$ & & & \\
\hline & Secale-type & $52.4^{\mathrm{a}}$ & & & \\
\hline Corylus & & & 0.025 & 1.400 & 0.042 \\
\hline Cyperaceae & & & 0.035 & 1.002 & 0.164 \\
\hline Fagus & & & 0.057 & 6.667 & 0.173 \\
\hline Juniperus & & & 0.016 & 2.067 & 0.036 \\
\hline \multirow[t]{8}{*}{ Other herbs } & & 26.6 & 0.02 & 2.207 & 0.188 \\
\hline & Asteraceae SF. Cichorioideae & $42.5^{\mathrm{b}}$ & & & \\
\hline & Filipendula & $14^{\mathrm{b}}$ & & & \\
\hline & Plantago lanceolata & $32^{\mathrm{b}}$ & & & \\
\hline & Potentilla-type & $25^{2}$ & & & \\
\hline & Ranunculus acris-type & $22^{\mathrm{b}}$ & & & \\
\hline & Rubiaceae & $26^{\mathrm{b}}$ & & & \\
\hline & Rumex acetosa-type & $25^{\mathrm{b}}$ & & & \\
\hline Picea & & & 0.056 & 1.757 & 0.000 \\
\hline Pinus & & & 0.031 & 5.663 & 0.000 \\
\hline Poaceae & & & 0.035 & 1.000 & 0.000 \\
\hline Quercus & & & 0.035 & 7.533 & 0.083 \\
\hline
\end{tabular}

The fall speeds of groups of pollen taxa are estimated based on Stoke's law (Gregory 1973) using measurements of pollen grain diameters (from (a) Beug 2004 and (b) Broström et al. 2004) 
when smaller-sized sites or a mixture of differently-sized sites are used. In our case, a first test run showed that when using one site (Fiolen) for application of the REVEALS model, the Relevant Source Area of Pollen (RSAP) was not always reached and hence the reconstruction of local vegetation was not possible (results not shown). Accordingly, we used pollen data from two sites for the reconstruction of the regional vegetation around each of our target sites, Åbodasjön and Lindhultsgöl: pollen records from Fiolen and Lindhultsgöl for the former site and from Fiolen and Åbodasjön for the latter. A first test showed that the selection of sites for regional reconstruction did not affect the REVEALS estimates (Fredh 2012).

Thereafter, the LOVE model was applied for reconstructing the local vegetation composition and land-use within the RSAP around Ảbodasjön and Lindhultsgöl separately. The LOVE model provides distance-weighted plant abundance within the RSAP, the smallest spatial unit for which vegetation abundance can be estimated by the model using fossil records (Sugita 2007b). Hereafter, the distance-weighted plant abundance will be referred to as LRA-based vegetation estimates. The RSAP is usually inferred from an inverse modelling approach of the LRA (Sugita 2007b; Sugita et al. 2010). Previous studies suggest that the RSAP is strongly influenced by the size of the pollen-sampling basins and the spatial patterns of the surrounding vegetation and land cover (e.g. Sugita 1994; Bunting et al. 2004; Mazier 2006; Hellman et al. 2009a; Hjelle and Sugita 2012) and that the reliability of the inferred RSAP depends on the number of similarly-sized sites available for data analysis (Sugita 2007b; Sugita et al. 2010). This project used the pollen record from only one site for vegetation reconstruction around each of Åbodasjön and Lindhultsgöl; thus it was difficult to obtain reliable RSAPs using the inverse modelling approach. Instead, we applied a forward-modelling approach (Sugita 1994; Sugita et al. 1999) for estimating the RSAPs using simulations with simple, hypothetical landscapes based on modern vegetation maps at a $100 \times 100 \mathrm{~km}$ plot, by combining satellite maps of southern Sweden and Swedish CORINE land-cover data (Hellman et al. 2008a, b). The predicted RSAPs for ̊̊bodasjön and Lindhultsgöl are within radii of 1,740 and $1,440 \mathrm{~m}$ from the lake centres, respectively. These RSAPs are hereafter considered as the spatial units of vegetation reconstruction around the sites.

Ideally a LRA application uses pollen records from a few lakes $>100$ ha and several small and similarly-sized lakes $<10-20$ ha for reliable estimates of regional vegetation, RSAP and local vegetation composition within RSAP. Because of the small number of lakes used in this project, however, the LOVE results were further evaluated using the qualitative assessment of difference (QAD) method (Sugita et al. 2006). This method effectively neutralizes the background pollen signal and evaluates between-site differences in plant abundances in the same region (Sugita et al. 2006). Although QAD results are expressed as +, or zero (i.e. ordinal qualitative data, not the magnitude of difference), those are much more objective than those evaluated by pollen percentages alone in theory and practice. The number of assumptions, parameters and pollen sites required for QAD is much smaller than that for LRA; QAD uses only pollen counts from a pair of similarly-sized sites and pollen productivity estimates for individual taxa. Accordingly the number of sites we use in this project is not the constraint for this method. One of the main assumptions is that the RSAP is consistent at a pair of sites compared through time; that is, we do not need to estimate the RSAP, one of the difficult parameters to obtain in the LRA when the number of sites is limited (Sugita 2007b). Although this assumption may be violated at Åbodasjön and Lindhultsgöl, the QAD results provide complementary assessments of the differences in the LRA-based vegetation estimates between the two sites.

All the parameter values used for REVEALS, LOVE and QAD and assumptions for those models are listed in the next section. The effects of departure from the assumptions on the model outputs are discussed in detail elsewhere (e.g. Sugita et al. 2006; Sugita 2007a, b; Hellman et al. 2008b; Sugita et al. 2010; Mazier et al. 2012). This study uses fourteen plant/pollen types for LRA and QAD: Picea, Pinus, Alnus, Betula, Quercus, Car.Fra.Til.Ulm, Fagus, Corylus, Juniperus, Calluna, Cyperaceae, Poaceae, Other herbs and Cereals (sum). The selection criteria for those taxa are discussed in detail in the section below.

Parameter values, and plant/pollen taxa used for reconstruction of vegetation and land cover with the LRA

The REVEALS, LOVE, and QAD models require raw pollen counts and parameter inputs including site radius (m), fall speed of pollen (FSP, $\mathrm{m} \mathrm{s}^{-1}$ ), pollen productivity estimates (PPEs) and their standard errors (SEs). The site radii $(\mathrm{m})$ were calculated from the total area (ha) of the study lakes, assuming circular shapes. The radii were set to $714 \mathrm{~m}$ for Fiolen, $400 \mathrm{~m}$ for Åbodasjön and $150 \mathrm{~m}$ for Lindhultsgöl, assuming constant site radii and PPEs through time. We used PPEs, SEs from southern Sweden and fall speeds of 24 relevant taxa as established in the literature (Eisenhut 1961; Sugita et al. 1999; Broström et al. 2004, 2008; Nielsen 2004). A first test run showed that the RSAP was not reached for several time windows when including rare taxa (i.e. Carpinus, Fraxinus, Tilia, Ulmus; see Table 1 for complete list). The LRA-based estimates for rare taxa tend to be small with relatively large 
SEs because of low pollen counts, and the RSAP estimate can be sensitive to those rare taxa. Therefore it is better to restrict the number of taxa used for the LRA approach for reliable reconstruction. The rare taxa were merged into three groups of pollen types [Car.Fra.Til.Ulm, other herbs and Cereals (sum)] with similar fall speed and ecology, as listed in Table 1. Their pollen counts were summed for each time interval. Values of fall speed for these pollen-groups were estimated from the mean diameter of all pollen types included in a group, size measurement were given in the literature (Beug 2004; Broström et al. 2004). This mean diameter was then used to calculate the pollen-group FSP based on Stoke's law (Gregory 1973). These three groups are referred to as taxa in the paper. Their mean PPEs and SEs were estimated using the delta method (Stuart and Ord 1994). This study used fourteen plant/pollen types for LRA and QAD: Picea, Pinus, Alnus, Betula, Quercus, Car.Fra.Til.Ulm, Fagus, Corylus, Juniperus, Calluna, Cyperaceae, Poaceae, other herbs and Cereals (sum). Although the PPEs of herbs, particularly cultivated types, may have changed through time, we do not have reliable estimates of the magnitude of changes for major crop cultivars in northern Europe, thus we assume that PPEs used have not changed in the past.

We used the REVEALS v.2.2.2.exe and LOVE v.3.2.0 computer programs (Sugita, unpublished), assuming neutral atmospheric conditions and an average wind speed of $3 \mathrm{~m} \mathrm{~s}^{-1}$ as in Prentice (1985) and Sugita (1993, 1994, 2007a, b). The Ring Source model (Sugita 1993) of pollen dispersal and deposition for lakes and ponds was used, and Zmax, the maximum spatial extent of the regional vegetation from the centre of the study sites, was set to $50 \mathrm{~km}$ as in Mazier et al. (2012).

Historical changes in land-use and human population over the last 200 years

This study classifies the land-use categories differently for the two sets of maps in such a way that the areas of individual land-use types can be compared with the LRA-based estimates. For the storskifte and laga skifte reform maps, the land-use categories included outland, meadow, cropland, wetland, lake and buildings, as compared to woodland, clear-cut, grassland, cropland, wetland, lake and buildings for the economic maps and orthophotos. Cadastral maps and orthophotos covering areas within $2 \mathrm{~km}$ radii (ca. RSAPs) around Åbodasjön and Lindhultsgöl were collected, rectified and digitized in vector format. The storskifte and laga skifte reform maps and economic maps were rectified using control points (i.e. cross-roads, lake borders and administrative borders) on a geo-referenced modern base map. In all cases the land-use categories were classified accordingly, and their areas were estimated from the maps using ArcGIS 9.2.
In each time period, the proportions of the areas $\left(\mathrm{m}^{2}\right)$ occupied by individual land-use types were estimated in each concentric ring at $20 \mathrm{~m}$ increments out to $2,000 \mathrm{~m}$ from the lake shore using ArcGIS 9.2. For the storskifte and laga skifte reform maps, non-classified areas, which varied from 8 to $31 \%$ in individual concentric rings, were excluded from the calculations, as were the non-pollenproducing areas (i.e., buildings, lakes and clear-cut).

The LRA approach provides vegetation estimates expressed as distance-weighted plant abundance within the RSAP. Pollen counts for each taxon from several 20 year intervals were merged according to the time span of the maps. The LRA-based estimates of individual taxa were grouped into the pollen-producing land-use categories described in the maps. Each of the fourteen taxa was assigned to one of the land-use categories specifically classified for this study-mainly representative of the taxa in that landuse category today-although some taxa may appear in several categories (Fig. 3).

For the comparisons with the LRA-based vegetation estimates, the vegetation data extracted from historical maps need to be distance-weighted. Therefore cumulative estimates of the land-use composition within 2,000 m radii were calculated around the two lakes, using a distanceweighted method. Each land-use type was assumed to be represented by a group of taxa according to Fig. 3 (i.e. meadow included Poaceae, other herbs and Corylus), and a model of pollen dispersal and deposition for lakes (Sugita 1993) was used for distance weighting. The fall speed of pollen (FSP), necessary for distance weighting, was calculated by averaging the diameter of all the pollen types included in a land-use category (Fig. 3) and by applying Stoke's law (Gregory 1973). The FSP of the land use categories was set to $0.034,0.037,0.024,0.027,0.037$ and $0.078 \mathrm{~m} \mathrm{~s}^{-1}$ for outland, woodland, grassland, meadow, wetland and cropland, respectively.

Population data for the study area were derived from parish church books from 1571 to 1900 according to Andersson Palm (2000). Additional population data based on church book chronicles (1750-2000) provided by local historical societies were also used.

\section{Results}

Land-use changes based on historical maps and orthophotos

This section describes the land-use changes within $2 \mathrm{~km}$ radii based on the original percentage cover obtained from the maps (Table 2; Fig. 4). The storskifte reform maps in the late 1700 s and early 1800s show that, around Abodasjön and Lindhultsgöl, outland (common lands) covers 
Fig. 3 Harmonisation of the land-use categories with corresponding taxa included in the LRA analysis. For comparison with the LOVE results, individual taxa are assigned to specific land-use categories (red lines) but may appear also in several other land-use categories (grey lines)

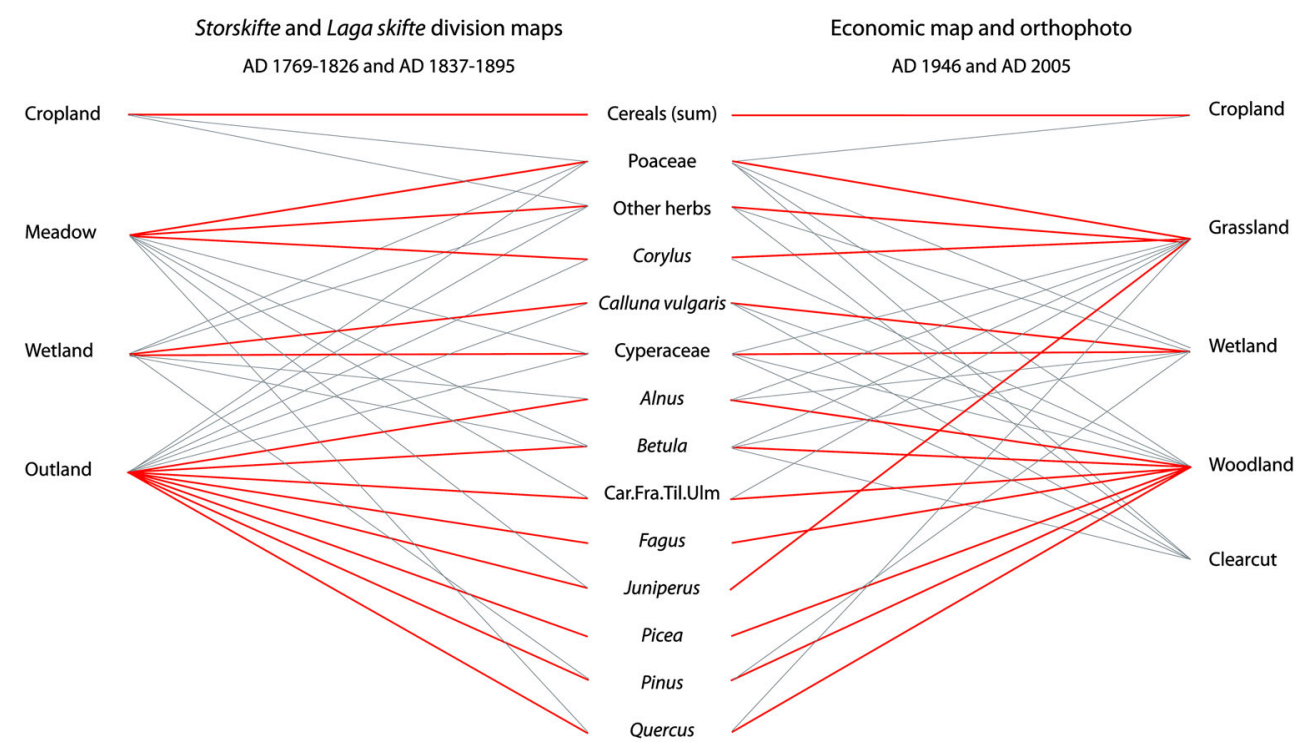

42 and $49 \%$, meadow 21 and $21 \%$, cropland 2 and $3 \%$, and wetland 3 and $15 \%$, respectively (Fig. 4; Table 2). The laga skifte reform maps in the late 1800s indicate that: (1) the outland expanded a few percent from that in the previous reform period around Åbodasjön, (2) the cropland was doubled in area around both lakes, and (3) the meadow area was reduced accordingly around both lakes. In total, 14 and $20 \%$ of the total areas were transformed around Åbodasjön and Lindhultsgöl, respectively. Between the late 1800 s and mid-1900s more than $60 \%$ of the total cover around the lakes was converted to other land-use types. Most of the converted areas became woodland, shifting mostly from outland and meadows; the area of cropland also doubled to ca. $12 \%$ around both lakes. The cover of wetland increased a few percent around Lindhultsgöl and one percent around Åbodasjön. Between the mid-1900s and 2005, the major changes were the increase in clear-cut and the conversion of grassland, wetland and cropland to coniferous woodlands (Table 2). In comparison with the previous period the area of cropland was reduced to half around both lakes, and the wetland decreased from 17 to $12 \%$ around Lindhultsgöl (Fig. 4). In total ca. $40 \%$ of the area around each lake was converted to other landuse types.

Comparison of historical map-based estimates with the LRA-based reconstruction

Results from the LOVE model are expressed as percentage covers of individual taxa that are based on the distanceweighted plant abundance within the RSAP (Sugita 2007b). Therefore we compared the LOVE-based estimates of vegetation with the distance-weighted plant abundance derived from the historical maps within a $2 \mathrm{~km}$ radius area around each site (Fig. 5). The results are comparable in general. The LRA-based estimates of cropland areas were similar to those from historical maps, except for the laga skifte reform and economic map periods at Lindhultsgöl and for the storskifte reform period at Åbodasjön, where the LRA slightly overestimated the cropland cover. The LRAbased estimates of wetland cover corresponded well to those from the historical maps at Åbodasjön for the four periods, but were overestimated for periods of the laga skifte reform and the economic map at Lindhultsgöl. The LRA-based estimates of meadows corresponded well to those in the storskifte and laga skifte reform periods at Åbodasjön, but were slightly overestimated at Lindhultsgöl.

Except for the economic map period at Åbodasjön, the grassland cover was highly overestimated in the LRA reconstruction. The cover of outland was broadly similar between the LRA- and map-based reconstruction at both sites in the storskifte and laga skifte reform periods. However, the outland cover around Lindhultsgöl was underestimated by the LRA reconstruction for the storskifte reform period. For the two latest periods, the LRA-based woodland cover was underestimated relative to that using the historical maps, except for the orthophoto period at Lindhultsgöl.

LRA-based reconstruction of local vegetation and landuse dynamics

The differences between the LRA-based estimates and the pollen percentages (Fig. 6) are particularly important for six taxa: Betula, Calluna, Corylus, Poaceae, Pinus and Picea. In comparison to their LRA-estimated abundance, Calluna, Corylus, Poaceae and Picea are underrepresented in pollen percentages, whereas Pinus and Betula are 
Table 2 Proportional cover of non distance-weighted land-use categories (upper panels) and landuse change (lower panels) within $2 \mathrm{~km}$ radii around Åbodasjön and Lindhultsgöl

\begin{tabular}{|c|c|c|c|c|c|c|c|c|}
\hline \multirow{2}{*}{$\begin{array}{l} \\
\text { Map/photo } \\
\text { Years represented }\end{array}$} & \multicolumn{4}{|c|}{ Lake Åbodasjön } & \multicolumn{4}{|c|}{ Lake Lindhultsgöl } \\
\hline & $\begin{array}{l}\text { Storskifte } \\
1801-1823\end{array}$ & $\begin{array}{l}\text { Laga skifte } \\
1837-1895\end{array}$ & $\begin{array}{l}\text { Economic } \\
1946\end{array}$ & $\begin{array}{l}\text { Orthophoto } \\
2005\end{array}$ & $\begin{array}{l}\text { Storskifte } \\
1801-1823\end{array}$ & $\begin{array}{l}\text { Laga skifte } \\
1837-1895\end{array}$ & $\begin{array}{l}\text { Economic } \\
1946\end{array}$ & $\begin{array}{l}\text { Orthophoto } \\
2005\end{array}$ \\
\hline \multicolumn{9}{|l|}{ Land-use categories } \\
\hline Outland & 42 & 45 & & & 49 & 48 & & \\
\hline Woodland & & & 61 & 62 & & & 57 & 61 \\
\hline Clear-cut & & & 1 & 20 & & & & 13 \\
\hline Meadow/grassland & 21 & 23 & 16 & 4 & 21 & 22 & 13 & 6 \\
\hline Cropland & 2 & 6 & 12 & 6 & 3 & 6 & 12 & 7 \\
\hline Wetland & 3 & 3 & 4 & 2 & 15 & 14 & 17 & 12 \\
\hline Lake & & 5 & 6 & 6 & 1 & 1 & 1 & 1 \\
\hline Building & & & & 1 & & & & \\
\hline No data & 31 & 19 & & & 10 & 8 & & \\
\hline Total area & 100 & 100 & 100 & 100 & 100 & 100 & 100 & 100 \\
\hline \multicolumn{2}{|c|}{ Differences between maps } & $\begin{array}{r}\text { Storskifte \& } \\
\text { laga skifte }\end{array}$ & $\begin{array}{l}\text { Laga skifte \& } \\
\text { economic }\end{array}$ & $\begin{array}{r}\text { Economic \& } \\
\text { orthophoto }\end{array}$ & $\begin{array}{r}\text { Storskifte \& } \\
\text { laga skifte }\end{array}$ & $\begin{array}{l}\text { Laga skifte \& } \\
\text { economic }\end{array}$ & $\begin{array}{r}\text { Economic \& } \\
\text { orthophoto }\end{array}$ & \\
\hline \multicolumn{2}{|c|}{ Total land without changes } & 51 & 19 & 57 & 61 & 23 & 62 & \\
\hline \multicolumn{2}{|c|}{ No data } & 14 & 61 & 1 & 19 & 9 & 1 & \\
\hline \multicolumn{2}{|c|}{ Total land with changes } & 35 & 19 & 42 & 20 & 68 & 37 & \\
\hline \multicolumn{2}{|c|}{ Meadow/grassland to cropland } & 2 & 4 & 1 & 2 & 4 & 1 & \\
\hline \multicolumn{2}{|c|}{ Outland to cropland } & 1 & 1 & & 1 & 2 & & \\
\hline \multicolumn{2}{|c|}{ Cropland to meadow/grassland } & & 1 & 2 & & 1 & 3 & \\
\hline \multicolumn{2}{|c|}{ Outland to meadow/grassland } & 4 & 3 & & 3 & 3 & & \\
\hline \multicolumn{2}{|c|}{$\begin{array}{l}\text { Coniferous woodland to } \\
\text { meadow/grassland }\end{array}$} & & & & & & 1 & \\
\hline \multicolumn{2}{|c|}{ Meadow/grassland to outland } & 3 & & & 6 & & & \\
\hline \multicolumn{2}{|c|}{ Wetland to outland } & 1 & & & 4 & & & \\
\hline \multicolumn{2}{|l|}{ Lake to wetland } & & & 1 & & & & \\
\hline \multicolumn{2}{|l|}{ Outland to wetland } & 1 & 1 & & 4 & 5 & & \\
\hline \multicolumn{2}{|c|}{ Meadow/grassland to wetland } & & 1 & & & 1 & & \\
\hline \multicolumn{2}{|c|}{ Outland to coniferous woodland } & & 38 & & & 38 & & \\
\hline \multicolumn{2}{|c|}{ Coniferous woodland to wetland } & & & & & & 2 & \\
\hline \multicolumn{2}{|c|}{$\begin{array}{l}\text { Meadow/grassland to } \\
\text { coniferous woodland }\end{array}$} & & 8 & 8 & & & & \\
\hline \multicolumn{2}{|c|}{ Wetland to coniferous woodland } & & 1 & 3 & & & & \\
\hline Cropland to coniferc & s woodland & & & 3 & & & & \\
\hline $\begin{array}{l}\text { Deciduous woodlan } \\
\text { coniferous woodl }\end{array}$ & & & & 1 & & & & \\
\hline $\begin{array}{l}\text { Meadow/grassland } t \\
\text { deciduous woodla }\end{array}$ & & & 1 & 3 & & & & \\
\hline Grassland to conifer & us woodland & & & & & 9 & 7 & \\
\hline Wetland to conifero & woodland & & & & & 4 & 6 & \\
\hline Cropland to coniferc & s woodland & & & & & & 3 & \\
\hline Grassland to decidu & is woodland & & & & & 1 & 1 & \\
\hline Cropland to deciduo & S woodland & & & 1 & & & 1 & \\
\hline Outland to deciduou & woodland & & 1 & & & & & \\
\hline $\begin{array}{r}\text { Coniferous woodlan } \\
\text { deciduous woodla }\end{array}$ & & & & 1 & & & & \\
\hline Coniferous woodlan & to clearcut & & & 15 & & & 11 & \\
\hline Deciduous woodlan & to clearcut & & & 1 & & & & \\
\hline Grassland to clearcu & & & & 3 & & & 1 & \\
\hline Other & & 1 & 2 & 1 & 1 & 1 & 2 & \\
\hline
\end{tabular}




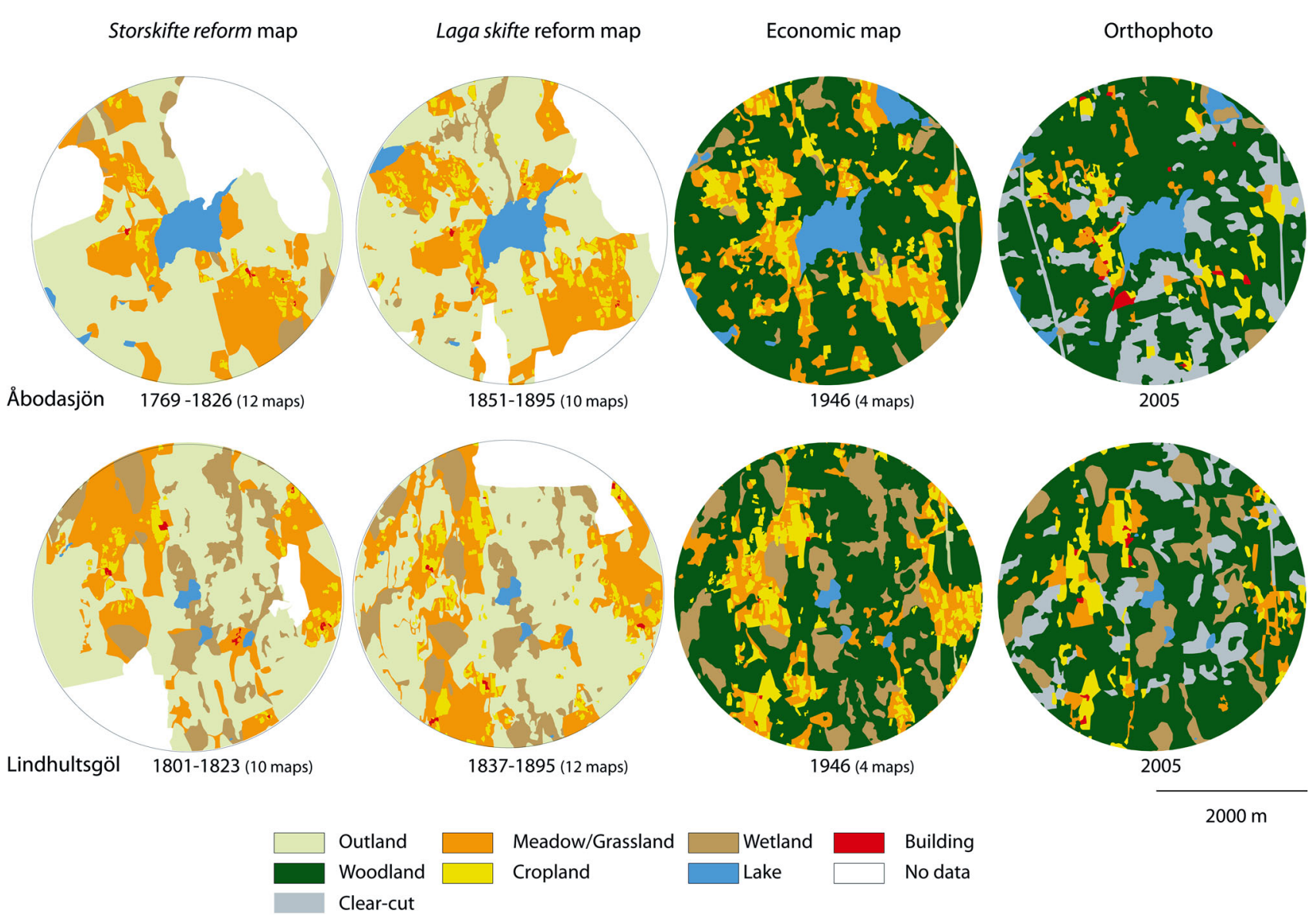

Fig. 4 Documented land-use categories derived from historical maps and orthophotos available within 2 km radii around Åbodasjön and Lindhultsgöl

\section{Åbodasjön}
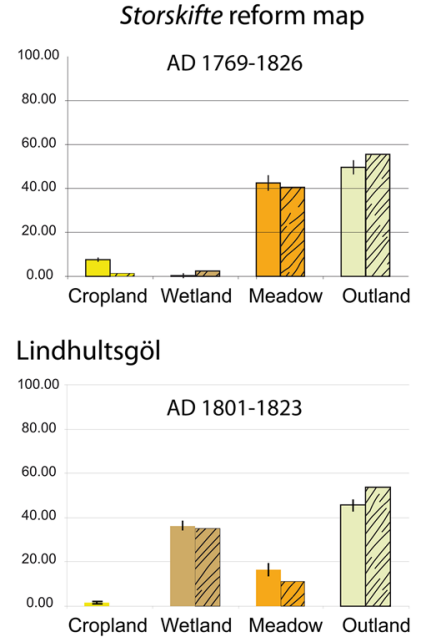
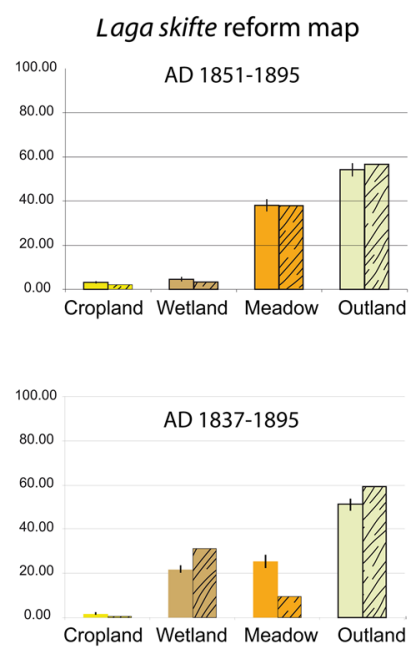

Fig. 5 Comparison of LRA-based estimates and distance-weighted plant abundances derived from historical maps and orthophotos expressed as land-use categories. For the laga skifte reform and storskifte reform maps, four land-use categories are compared: cropland, wetland, meadows and outland. For the economic maps
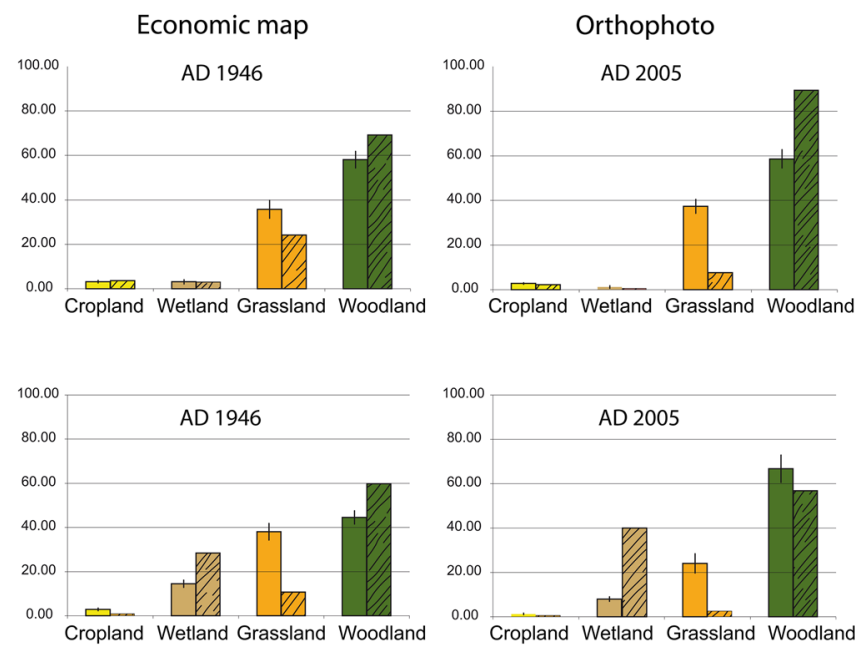

and orthophotos, four partly different land-use categories are compared: cropland, wetland, grassland and woodland. The LRA-based estimates for each taxon are grouped into land-use categories according to Fig. 3. The open and hatched histograms represent LRA- and map-based estimates, respectively 
overrepresented in pollen percentages. Hereafter we will only describe the LRA-based reconstruction of local vegetation.

\section{Åbodasjön (Fig. 6)}

Over the last 200 years landscape openness based on herb taxa cover varied between 12 and $27 \%$; if Corylus and $\mathrm{Ju}$ niperus were assumed to be growing mainly on grazed areas it varied between 31 and $59 \%$. The highest openness occurred in 1860-1900 and decreased thereafter. Total tree cover increased consistently from 34 to $64 \%$ mainly because of the significant increases in the percentage covers of Picea and Pinus. The percentage cover of Picea increased from $9 \%$ in 1900-1920 to $27 \%$ in the most recent interval. Among the deciduous trees, the percentage covers of Fagus and Quercus were consistently low over the last 200 years. Calluna was always low in percentage cover. Four time zones with significant changes in local vegetation were as follows:

1800-1860: The landscape was semi-open, characterized by ca. $40 \%$ and ca. $50 \%$ of forested and unforested vegetation, respectively. The major tree taxa were Alnus, Pinus and
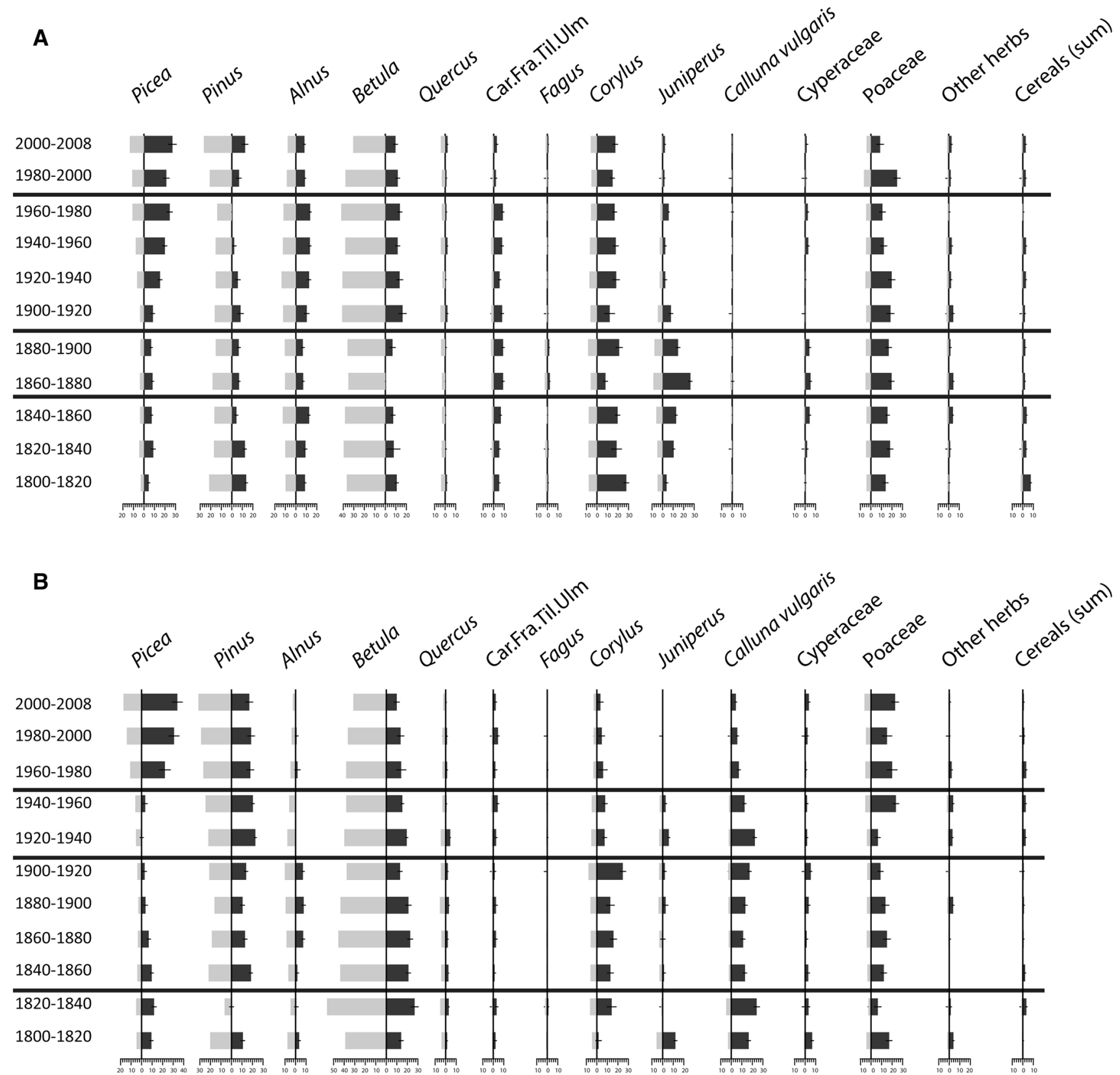

Fig. 6 Pollen percentages (grey histograms) and LRA-based estimates of vegetation composition (black histograms) based on 14 taxa for a Åbodasjön and b Lindhultsgöl. The horizontal lines represent local vegetation zones identified by constrained cluster analysis (Coniss; Grimm 1987) 
Betula, and the characteristic shrubs and herbs Corylus (ca. $25 \%$ ) and Poaceae (ca. $15 \%$ ). The percentage cover of $J u$ niperus increased during the entire period and the highest percentage cover of Cereals (ca. $8 \%$ ) occurred in this period.

1860-1900: Open-land vegetation taxa, such as Corylus and Poaceae (ca. $40 \%$ ) with abundant Juniperus (ca. $15 \%)$ characterized this period. The percentage cover of Betula and Alnus dropped to their lowest values, especially Betula that was absent in 1860-1880. The percentage cover of deciduous taxa, i.e. Car.Fra.Til.Ulm and Fagus, in this period reached the highest values of the last 200 years.

1900-1980: Woodland areas increased to ca. $60 \%$ in this period. Picea, Alnus and Betula become more dominant than before. The transition from the previous zone is characterized by the percentage cover increase in Alnus and Betula and the decrease in Juniperus. The percentage cover of Picea increased throughout this period, while that of Pinus became low and eventually disappeared locally at the end of the period. The Juniperus cover decreased dramatically during this period.

1980-2008: The total tree cover was similar to that in the previous period. However, Picea, Pinus, Betula and Alnus became more dominant, especially Pinus, which differed from the 1900-1800 period. The Poaceae cover decreased and became low in this period.

\section{Lindhultsgöl}

The percentage cover of unforested areas varied between 8 and $21 \%$ over the last 200 years, and between 20 and $38 \%$ when Juniperus and Corylus were included. The total tree cover increased from 40 to $70 \%$ with a significant increase in 1960-1980. On the contrary the wetland cover, characterized by Calluna vulgaris and Cyperaceae, decreased from 27 to $8 \%$. Juniperus and deciduous broadleaved taxa, especially Fagus, were not abundant locally throughout the period, except for Betula which was abundant consistently. Four time zones with significant changes in local land-cover were classified as follows:

1800-1840: The landscape was characterized by woodland (ca. $45 \%$ ), open areas (ca. $30 \%$ ) and wetlands (ca. $25 \%$ ). The dominant taxa were Picea, Betula, Calluna and Poaceae.

1840-1920: Compared to the previous period, there was a shift in the coniferous woodland composition: a decrease in the percentage cover of Picea and an increase in that of Pinus. The dominant taxa were Pinus, Betula, Corylus, Calluna and Poaceae.

1920-1960: This zone is defined by decreases in the percentage cover of Alnus, Corylus and Calluna vulgaris and increases in Pinus and Poaceae.

1960-2008: The forested area increased to ca. $70 \%$ and the wetland cover decreased to $8 \%$. The percentage cover of Picea and Pinus became 35 and $20 \%$, respectively.
Abundant Betula and Poaceae in the landscape also characterized this period.

Differences in vegetation and land-use between Åbodasjön and Lindhultsgöl: LRA versus QAD

In general, the differences in the LRA-based reconstruction of vegetation and land cover between the two sites were consistent with those indicated by the QAD results (Fig. 7). Among the 154 pairs of comparisons possible between the two sites (i.e., 11 time windows $\times 14$ plant taxa/classes), 43 cases showed differences in the rank order between the sites for the LRA- and QAD-based estimates. These cases were mostly for low-abundance taxa/classes, such as other herbs, Cereals (sum) and broadleaved deciduous trees (Car.Fra.Til.Ulm). For example, the results indicate that Car.Fra.Til.Ulm was more abundant locally at Åbodasjön than at Lindhultsgöl in 1860-1880. However the QAD results show that there were no significant differences in these taxa between the two sites. Thus, interpretations of these cases using the LRA-based estimates of low-abundance taxa need caution.

Several taxa were locally more abundant at Åbodasjön than at Lindhultsgöl, such as Alnus (5-13\%), Corylus (8-26\%), Juniperus (2-26\%), and Car.Fra.Til.Ulm (5-7\%), except for the periods when these taxa were about equally abundant at the two sites, i.e. 1860-1900, 1820-1840, 1940-1960 and 1820-1840/2000-2008 respectively. In general, the percentage covers of Calluna (4-24\%) and Pinus (4-18\%) were larger at Lindhultsgöl, except in 1820-1840 when the abundance of Pinus was higher (12\%) than at Åbodasjön, and in 1800-1820 and 2000-2008 when the abundance of Pinus was the same at the two sites. The percentage covers of Betula (13-23\%) and Quercus (2-4\%) were higher at Lindhultsgöl than at the other lake in 1820-1900. The percentage cover of Cyperaceae was mostly similar between the two sites in 1980-2008 and those of Picea and Poaceae were mostly the same in 1800-1900. However, the patterns of change in percentage cover of these taxa diverged significantly between the sites after 1900 .

\section{Discussion and conclusions}

Advantages and disadvantages of pollen data and historical maps for land-use reconstruction

\section{Pollen-based approach}

This study uses pollen data from two different-sized lakes to estimate regional vegetation abundance for the reconstruction of the local vegetation at individual small lakes (Åbodasjön and Lindhultsgöl). A similar study in the same 


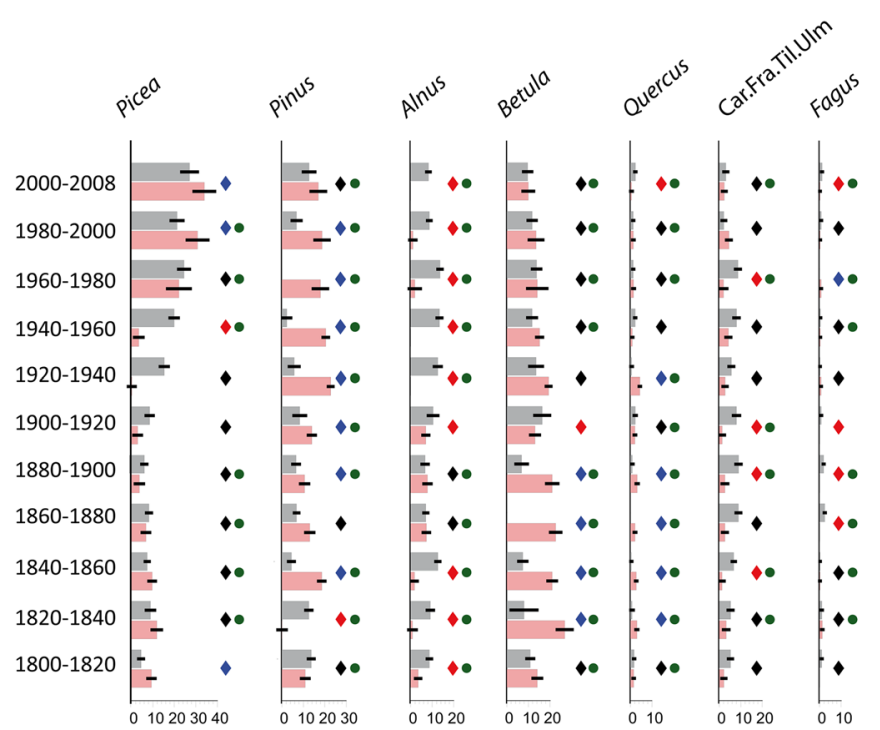

Fig. 7 LRA-inferred local vegetation compositions based on 14 taxa for Abodasjön (grey) and Lindhultsgöl (pink) compared with the output of the QAD method. The QAD results are indicated by solid diamonds on the right-hand side of each taxon. The colour code for

region ( $\mathrm{Cu}$ 2013; Cui et al. 2014) concluded that there are clear similarities between the regional estimates. Moreover, the general agreement between the LRA- and QADbased results provides confidence in the interpretation of the differences in vegetation and land-use cover between the two sites, even though some of the assumptions of both approaches are not fully satisfied.

Because the LRA approach is a multi-step process with many parameters, the propagation of errors is an important issue. The number and location of sites, sizes and character of basins, pollen productivity estimates, total pollen counts and chronological control of the records all affect the error estimates (Sugita 2007b). The optimum number of sites for reliable LRA outputs varies depending on the spatial heterogeneity of the vegetation and land cover. In general, however, the larger the number of sites the better the vegetation reconstructions. Previous studies indicate that pollen data from 2 to 5 large lakes ( $>100-500$ ha) provide reliable estimates of regional vegetation composition using the REVEALS model (Hellman et al. 2008a, b). Pollen records from a number of smaller-sized sites can also be used for regional vegetation reconstruction by averaging out the between-site differences in pollen assemblages, although error estimates are usually large (Sugita 2007a), as well as pollen records from a number of sites of different size (Sugita 2007a; Mazier et al. 2012). High pollen counts reduce the uncertainties of both regional and local vegetation estimates; a minimum of 1,000 grains is generally recommended (Sugita 2007b, Sugita et al. 2010, Mazier et al. 2012). This study was based on 1,000-2,330

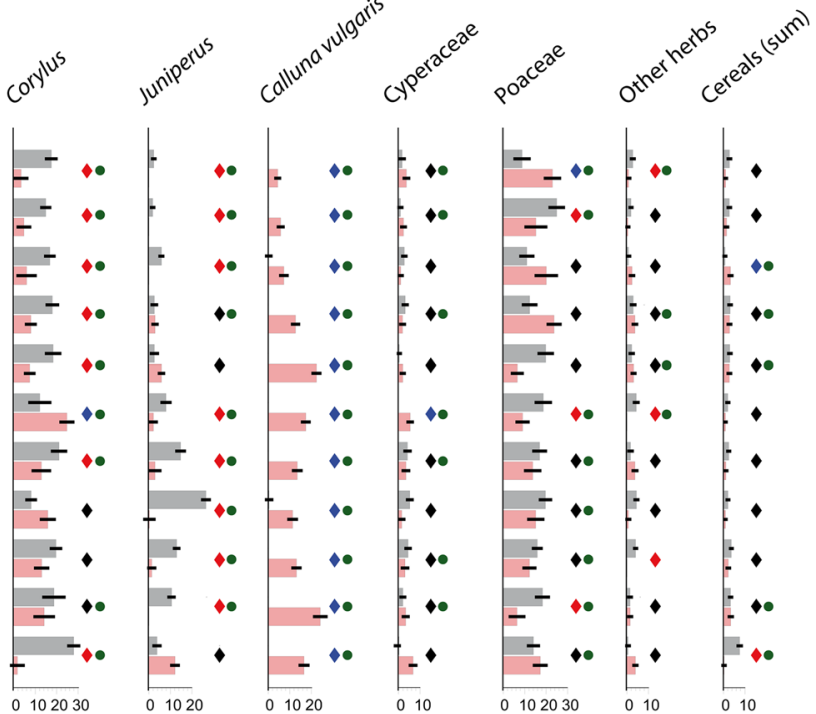

the diamonds indicate when the QAD-based direction between Åbodasjön and Lindhultsgöl is negative (blue), positive (red) or insignificant (black). The green dots indicate level of similar direction of differences in plant abundance for both QAD and LRA approaches

pollen grains counted at time intervals of 20 years in order to reduce the uncertainties.

Reliable estimates of past RSAP require pollen records from several similar-sized sites (Sugita 2007b; Sugita et al. 2010). This study uses the simulation-based estimates of the past RSAP — the area within a 1,740 m radius at Åbodasjön and a 1,440 $\mathrm{m}$ radius at Lindhultsgöl. These are similar to the estimates for Danish lakes (3-27 ha) based on historical maps in 1800 (Nielsen and Sugita 2005) and to the estimates for Småland peatbogs (same area as our study, Cui et al. 2014) based on the forward modeling approach. Consistent with Nielsen and Odgaard (2010), we assume that the RSAP is constant through time for our reconstruction. Although this assumption is reasonable for the last 200 years, further evaluation with more forwardand inverse-modelling is necessary (Sugita 2007b).

This study selects the most reliable dates possible for establishing the age-depth model at each lake (Fredh et al. 2013; Bragée et al. 2013a). For the last 200 years, the uncertainty envelopes at the $95.4 \%$ confidence level are 2-119 years for Åbodasjön, 4-156 years for Lindhultsgöl, and 1-260 years for Fiolen. These uncertainty estimates show that relatively large deviations from the ages used in this study are possible, especially in the older parts of the records.

\section{Map-based approach}

The maps from the storskifte and laga skifte reform periods include detailed land-cover information of a high technical 
and geometric quality (Örback 1998); thus the rectification of the maps is reliable. The standardized identification of cropland, meadows, wetland and outland in these maps (ESM) together with supplementary information from associated written documents proved to be valuable. However, the map-based estimates of the composition and percentage cover of individual taxa in each of the land-use categories are not precise. There was no distinction of different cultivated crops on the maps, the cropland category includes mainly cereals, but could also encompass potatoes, grass or leguminous plants (Cui et al. 2014). The surveyors describe the meadows with respect to their quality and productivity, the forest with comments about sufficiency, and the outland with information about tree sizes, quality of grazed vegetation and sometimes the use of trees as leaf fodder (Dahlström 2008). Therefore the main difficulty and source of error in our comparison with the LRA output is that trees and shrubs often grow in the meadows, and the outland was used for grazing and the collection of fire wood (Gadd 2000). Some maps show tree symbols in the outland polygons with occasional notes and tables that indicate low tree cover in the outland, although quantification is difficult. In contrast, the interpretation of tree cover based on the aerial photographs from 1946 and 2005 is straightforward (Ihse and Norderhaug 1995).

The historical maps record the spatial extent of cropland, meadows and common lands. However, differences in the classification of land-use categories exist (Dahlström 2008). The maps in the storskifte and laga skifte reform periods were produced in 1769-1823 and 1837-1895, representing periods of 54 and 58 years respectively. Thus it is difficult to quantify the changes in terms of exact dates. Moreover, these maps do not always cover the villages and their surroundings which are within the $2 \mathrm{~km}$ radius of our study sites. Despite those deficiencies, however, the transition from traditional to modern agriculture in the late 1800 s based on the changes in the land-use categories can be depicted reasonably well.

\section{Potential and limitations}

The estimates of the land-use covers are comparable between the LRA-and map-based approaches. The LRA approach provides realistic estimates of the differences in cover of wetland (Lindhultsgöl $>$ Åbodasjön) and meadows (Lindhultsgöl < Åbodasjön) at the two sites in the early 1800s. The LRA-based estimates of cropland are also in good agreement with the map-based estimates for most of the 200 year period.

Taxonomic harmonization (Fig. 3) and the application of the distance-weighted method to historical maps are both necessary for a comparison of the LRA- and map-based vegetation estimates. We are aware that individual taxa may appear in several of the land-use categories (Fig. 3), such as Corylus, which grew partly in meadows (Ekstam and Forshed 1992; Morell 2001) and partly in woodland. Calluna can also grow in different vegetation types-i.e. conifer forests, bogs and grazed heaths. In a similar study in Småland (Cui et al. 2014), using comparable historical maps to ours, Calluna was found to be abundant in forest and bog categories on the two younger maps and in all three vegetation types on the two older maps. Another issue is the accuracy and mismatch of the time units in both records, i.e. the chronological uncertainties of the Fiolen sediment record and the large time span represented by the maps from the 1800s. From 1940 and onwards the chronological uncertainties are smaller; the temporal resolution of the economic maps and orthophotos is 1 year and that of the LRA results is 20 years. Further evaluation of the effects of these mismatches in temporal scales is necessary, although beyond the scope of this study.

The overestimation of the grassland cover in the LRA results relative to the economic maps and orthophoto around Åbodasjön is similar to that described in Nielsen and Odgaard (2010). Several explanations are possible. For example, the inclusion of Corylus in this land-use category for the LRA approach may distort the estimates of grassland cover (Fig. 5). The exclusion of the clear-cut area (usually treated as a non-pollen producing area), often characterized by graminoid plants including Poaceae taxa, can be another factor. This is directly and irreversibly linked to our assumptions of assigning each taxon to a unique land-use category. Underestimation of the LRAbased woodland relative to the orthophoto-based cover around Åbodasjön may be caused partially by young plantations of trees that do not produce pollen in great quantity. Matthias et al. (2012) show that Picea and Pinus reach their flowering age at 40 and 20 years, respectively. Therefore a young plantation will not produce much pollen while it will appear like a dense forest on an aerial photograph

Local land-use dynamics for the last 200 years around two lakes

This section integrates the LRA-based estimates of landuse changes and the historical development of the social, economic and technological aspects of the local communities to discuss the land-use dynamics around Åbodasjön and Lindhultsgöl (Fig. 8).

\section{Åbodasjön}

Over the last 200 years the landscape around the lake has remained relatively open, although mixed woodland has 


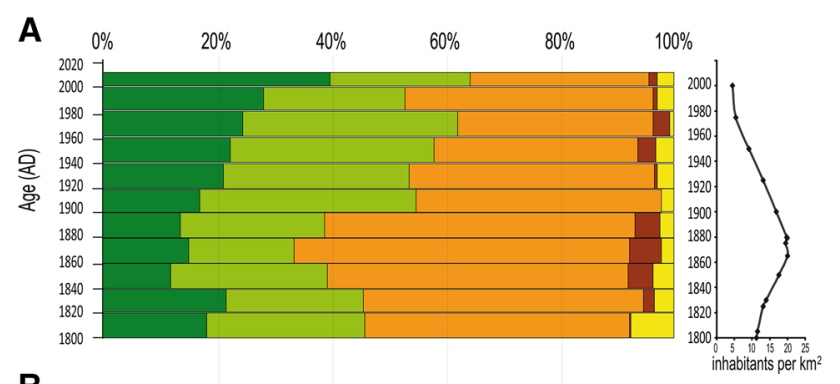

B

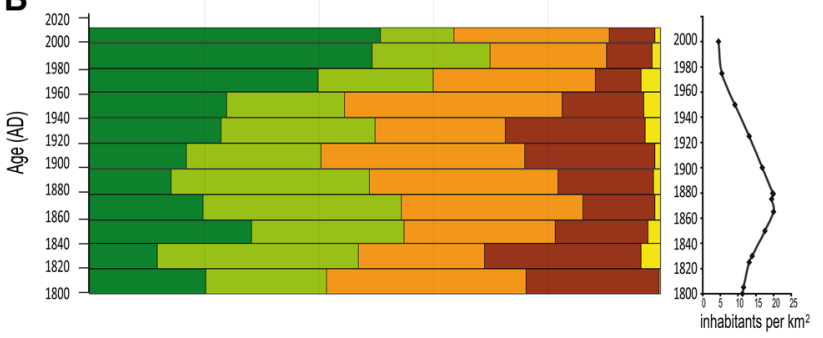

Fig. 8 LRA-based estimates of land-use coverage compared to the population development in Slätthög Parish for a Åbodasjön and b Lindhultsgöl Dark green indicates coniferous woodland, light green deciduous woodland, orange grassland (Corylus and Juniperus included), brown wetland and yellow cropland

become common in recent years. Landscape openness increased throughout the $1800 \mathrm{~s}$, mainly because of the grassland expansion. On the other hand, cropland decreased slightly between 1860 and 1920. Population increase and extensive land-use activities were the main causes of the vegetation and land-cover changes. The population of the parish increased from 11 to 20 inhabitants per $\mathrm{km}^{2}$ between 1800 and 1867 (Fig. 8), accelerating needs for grazing areas, hay meadows and cropland. In the 1800s large areas of outland were exploited for these purposes (Myrdal 1997). In 1867 a great famine occurred because of a harvest failure in southern Sweden, triggering an extensive migration of population to urban areas, as well as to the United States (Sundbärg 1883). The decline of rural population during the transition to modern agriculture in the late 1800s resulted in a significant increase of deciduous-woodland cover around the lake. Since then, coniferous woodland cover characterized by Pinus and Picea has increased right up to the present. The abandonment of grazing areas for cattle and the start of forestry in the late 1800s led to an increase of trees in the grasslands (Ekstam and Forshed 1992). The increase in cropland cover during the 1900s reflected the increase in agricultural efficiency and indicated a shift from the traditional agricultural practices to the modern systems. All these changes show that much of the human labour, self-sufficient agriculture, and interdependence between the land-use categories has become redundant in recent years (Emanuelsson 2009).

\section{Lindhultsgöl}

The landscape around Lindhultsgöl changed from a relatively open rural landscape, i.e. mixed grassland and wetland, to a wooded landscape characterized by Picea and Pinus over the last 200 years. In the early 1800 s hay meadows and croplands increased for a short period in the outland areas but afterwards, the deciduous woodland cover became significantly larger than before. The wetland cover has changed significantly since the early 1800 s: there was a dramatic decline in the mid-1800s, an increase around 1900, and a decline from 1920 to the present. Increased grazing and fodder pressure led to the decline of the wetland cover around mid-1800s. Soon after, however, these activities were abandoned until the early 1900s. Around 1940 the development of drainage systems, which aimed to improve forest lands for timber production, accelerated the decline of the wetland cover. After 1960 both Picea and Pinus characterized the woodlands. The codominance of these two taxa reflected the plantation history of Picea; in the 1800s the coniferous forests consisted mostly of Pinus (Fig. 6), but this changed dramatically at the beginning of the 1900s when the plantation of Picea started (Eliasson 2002).

Implications for long-term environmental analyses

The palaeoecological methods used in this study are useful for environmental management as they provide long-term records of ecosystem dynamics and response to land-use change (e.g. size, frequency and duration). Combinations of pollen-based reconstructions of past landscape, including the LRA- and QAD-based approaches, together with the historical maps enabled us to evaluate the reliability of the local vegetation and land-use estimates (Berglund 1991; Nielsen 2004; Dahlström 2008; Hellman et al. 2009b). Historical maps and aerial photographs were invaluable to describe spatiotemporal dynamics of land-use patterns in detail, for a better understanding of the effects of the past land-use practices on the modern landscape (Skånes and Bunce 1997; Cousins 2001; Johansson et al. 2008). On the other hand the historical maps are restricted to specific periods and cannot provide a continuous record of land-use and vegetation (Dahlström 2008). For this study area, the applications of the LRA approach with high-resolution pollen records provided detailed information on land-use dynamics for evaluating the impacts of human activities on biodiversity and ecosystem changes during recent millennia (Fredh et al. unpublished). The inferred changes in land-use were also used as input variables in an integrated local-scale evaluation of potential processes affecting trends in lake-water dissolved organic 
carbon (DOC) concentrations in Åbodasjön and Lindhultsgöl beyond the reach of monitoring data (Bragée et al. 2013b).

Acknowledgments We are very thankful to all members of the NordForsk network LANDCLIM (coordinated by M.J. Gaillard, Linnaeus University, Sweden) for useful and inspiring discussions during the numerous network workshops (2009-2011). This work was funded by the Swedish Research Council Formas through Grants 2006-547 to W. Granéli and 2007-1012 to A. Broström. S.S. was supported by the funding available through the Estonian Mobilitas Programme (MTT3), and F.M. by the French project ANR 2010 JCJC $180401 \ll$ MODE RESPYR $\gg$ (http://www.w3.mode-respyr.uni vtlse2.fr/index.php). We are also grateful to Sheila Hicks for careful checking and editing the text and to three reviewers (Thomas Giesecke and two anonymous) for valuable suggestions for revisions and corrections of an earlier version of the manuscript.

\section{References}

Alexandersson H, Karlström C, Larsson-McCann S (1991) Temperature and precipitation in Sweden, 1961-1990, Reference normals. SMHI report 81. Norrköping

Anderson J, Bugmann H, Dearing JA, Gaillard M-J (2006) Linking palaeoenvironmental data and models to understand the past and to predict the future. Trends Ecol Evol 21:696-704

Andersson Palm L. (2000) Folkmängden i Sveriges socknar och kommuner 1571-1997, Göteborg

Berglund BE (1991) The cultural landscape during 6,000 years in southern Sweden-the Ystad Project. Ecological Bulletins 41. Munksgaard International Booksellers and Publishers, Copenhagen

Berglund BE, Ralska-Jasiewiczowa M (1986) Pollen analysis and pollen diagrams. In: Berglund BE (ed) Handbook of Holocene palaeoecology and palaeohydrology. Wiley, Chichester, pp $155-484$

Beug H-J (2004) Leitfaden der Pollenbestimmung für Mitteleuropa und angrenzende Gebiete. Pfeil, München

Boyle JF (2000) Rapid elemental analysis of sediment samples by isotope source XRF. J Paleolimnol 23:213-221

Bragée P, Choudhary P, Routh J, Boyle JF, Hammarlund D (2013a) Lake ecosystem responses to catchment disturbance and airborne pollution: an 800-year perspective in southern Sweden. J Paleolimnol 50:545-560

Bragée P, Mazier F, Rosén P, Fredh D, Broström A, Granéli W, Hammarlund D (2013b) Forcing mechanisms behind variations in total organic carbon (TOC) concentration of lake waters during the past 8th centuries-palaeolimnological evidence from southern Sweden. Biogeosci Discus 10:19,969-20,003

Broström A, Sugita S, Gaillard M-J (2004) Pollen productivity estimates for the reconstruction of past vegetation cover in the cultural landscape of southern Sweden. Holocene 14:368-381

Broström A, Nielsen AB, Gaillard M-J et al (2008) Pollen productivity estimates of key European plant taxa for quantitative reconstruction of past vegetation-a review. Veget Hist Archaeobot 17:461-478

Bunting MJ, Gaillard M-J, Sugita S, Middleton R, Broström A (2004) Vegetation structure and pollen source area. Holocene 14:651-660

Cousins SAO (2001) Analysis of land-cover transitions based on 17th and 18th century cadastral maps and aerial photographs. Landscape Ecol 16:41-54
Cui Q (2013) Fire history in the hemiboreal and southern boreal zones of southern Sweden during 11000 years-Relationships with past vegetation composition and human activities and implications of biodiversity issues, Dissertation, Linnaeus University, Kalmar

Cui Q, Gaillard M-J, Lemdahl G, Stenberg L, Sugita S, Zernova G (2014) Historical land-use and landscape change in southern Sweden and implications for present and future biodiversity. Ecol Evol 4:3,555-3,570

Dahlström A (2008) Grazing dynamics at different spatial and temporal scales: examples from the Swedish historical record AD 1620-1850. Veget Hist Archaeobot 17:563-572

Daniel E (2009) Beskrivning till jordartskartan 5E Växjö NV. Sveriges geologiska undersökning K 168

Eisenhut G (1961) Untersuchungen über die Morphologie und Ökologie der Pollenkörner heimischer und fremdländischer Waldbaüme. Parey, Hamburg

Ekstam U, Forshed N (1992) Om hävden upphör. Kärlväxter som indikatorarter i ängs- och hagmarker, Naturvårdsverket, Solna

Eliasson P (2002) Skog, makt och människor. En miljöhistoria om svensk skog 1800-1875. Dissertation, Lund University, Lund

Emanuelsson U (2009) The rural landscapes of Europe-How man has shaped European nature. Forskningsrådet Formas, Stockholm

Fredh D (2012) The impact of past land-use change on floristic diversity in southern Sweden-a quantitative approach based on high-resolution pollen data. Dissertation, Lund University, Lund

Fredh D, Broström A, Zillén L, Mazier F, Rundgren M, Lagerås P (2012) Floristic diversity in the transition from traditional to modern land-use in southern Sweden AD 1800-2008. Veget Hist Archaeobot 21:439-452

Fredh D, Broström A, Rundgren M, Lagerås P, Mazier F, Zillén L (2013) The impact of land-use change on floristic diversity at regional scale in southern Sweden 600 BC-AD 2008. Biogeosciences 10:3,159-3,173

Gadd CJ (2000) Den agrara revolutionen 1700-1870. Natur och Kultur/LTs förlag, Stockholm

Gregory PH (1973) The microbiology of the atmosphere. A Plant science monograph. Leornard Hill, Aylesbury

Grimm EC (1987) CONISS: a FORTRAN 77 program for stratigraphically constrained cluster analysis by the method of incremental sum of squares. Comput Geosci 13:13-35

Gustafsson L, Ahlén I (1996) National Atlas of Sweden—geography of plants and animals. SNA publishing, Stockholm

Hellman S, Gaillard M-J, Broström A, Sugita S (2008a) Effects of the sampling design and selection of parameter values on pollenbased quantitative reconstructions of regional vegetation: a case study in southern Sweden using the REVEALS model. Veget Hist Archaeobot 17:445-459

Hellman S, Gaillard M-J, Broström A, Sugita S (2008b) The REVEALS model, a new tool to estimate past regional plant abundance from pollen data in large lakes-validation in southern Sweden. J Quat Sci 23:21-42

Hellman S, Bunting MJ, Gaillard MJ (2009a) Relevant source area of pollen in patchy cultural landscapes and signals of anthropogenic landscape disturbance in the pollen record: a simulation approach. Rev Palaeobot Palynol 153:245-258

Hellman S, Gaillard M-J, Bunting JM, Mazier F (2009b) Estimating the relevant source area of pollen in the past cultural landscapes of southern Sweden - a forward modelling approach. Rev Palaeobot Palynol 153:259-271

Hjelle K, Sugita S (2012) Estimating pollen productivity and relevant source area of pollen using lake sediments in Norway: how does lake size variation affect the estimates? Holocene 22:313-324

Ihse M, Norderhaug A (1995) Biological values of the Nordic cultural landscape: different perspectives. Int J Herit Stud 1:156-170 
Johansson LJ, Hall K, Prentice HC, Ihse M, Reitalu T, Sykes MT, Kindström M (2008) Semi-natural grassland continuity, longterm land-use change and plant species richness in an agricultural landscape on Öland, Sweden Landscape. Urban Plan 84:200-211

Matthias I, Nielsen A, Giesecke T (2012) Evaluating the effect of flowering age and forest structure on pollen productivity estimates. Veget Hist Archaeobot 21:471-484

Mazier F (2006) Modélisation de la relation entre pluie pollinique actuelle, végétation et pratiques pastorales en moyenne montagne (Pyrenees et Jura). Application pour l'interprétation des données polliniques fossiles. Dissertation, Université de Franche-Comté/Université de Neuchâtel

Mazier F, Gaillard MJ, Kuneš P, Sugita S, Trondman AK, Broström A (2012) Testing the effect of site selection and parameter setting on REVEALS-model estimates of plant abundance using the Czech Quaternary Palynological Database. Rev Palaeobot Palynol 187:38-49

Morell M (2001) Jordbruket i industrisamhället 1870-1945. Natur och Kultur/LTs förlag, Stockholm

Myrdal J (1997) En agrarhistorisk syntes. In: Larsson BMP, Morell M, Myrdal J (eds) Agrarhistoria. LTs Förlag, Stockholm

Nielsen AB (2004) Modelling pollen sedimentation in Danish lakes at C. AD 1800: an attempt to validate the POLLSCAPE model. J Biogeogr 31:1,693-1,709

Nielsen AB, Odgaard B (2010) Quantitative landscape dynamics in Denmark through the last three millennia based on the landscape reconstruction algorithm approach. Veget Hist Archaeobot 19:375-387

Nielsen AB, Sugita S (2005) Estimating relevant source area of pollen for small Danish lakes around $\mathrm{AD}$ 1800. Holocene 15: $1,006-1,020$

Nielsen AB, Giesecke T, Theuerkauf M et al (2012) Quantitative reconstructions of changes in regional openness in north-central Europe reveal new insights into old questions. Quat Sci Rev 47:131-149

Örback AIE (1998) Lantmäterikartorna som historisk källa. In: Sporrong U, Wennström H-F (eds) Sveriges Kartor: Sveriges Nationalatlas. Lantmäteriverket, Stockholm

Overballe-Petersen MV, Nielsen AB, Bradshaw RHW (2012) Quantitative vegetation reconstruction from pollen analysis and historical inventory data around a Danish small forest hollow. J Veg Sci 24(4):755-771

Prentice IC (1985) Pollen representation, source area, and basin size: toward a unified theory of pollen analysis. Quat Res 23:76-86

Prentice IC (1988) Records of vegetation in time and space: the principles of pollen analysis. In: Huntley B, Webb $\mathrm{T}$ (eds) Vegetation history. Kluwer, Dordrecht, pp 17-42

Punt W, Blackmore S, Clarke GSC, Hoen PP (1976-2009) The Northwest European Pollen Flora (NEPF) Vol I (1976), Vol II (1980), Vol III (1981), Vol IV (1984) Vol V (1988), Vol VI (1991), Vol VII (1996), Vol VIII (2003), Vol IX (2009). Elsevier, Amsterdam

Renberg I, Hansson H (2008) The HTH sediment corer. J Paleolimnol 40:655-659
Renberg I, Bigler C, Richard B, Matilda N, Rydberg J, Segerström U (2009) Environmental history: a piece in the puzzle for establishing plans for environmental management. J Environ Manag 90:2,794-2,800

Sjörs H (1963) Amphi-atlantic zonation, nemoral to arctic. In: Löve A, Löve D (eds) North Atlantic biota and their history. Pergamon Press, Oxford, pp 109-125

Skånes HM, Bunce RGH (1997) Directions of landscape change (1741-1993) in Virestad, Sweden — characterised by multivariate analysis. Landscape Urban Plan 38:61-75

Soepboer W, Sugita S, Lotter AF (2010) Regional vegetation-cover changes on the Swiss Plateau during the past two millennia: a pollen-based reconstruction using the REVEALS model. Quat Sci Rev 29:472-483

Stuart A, Ord JK (1994) Kendall's advanced theory of statistics. Distribution theory, Vol 1 Edward Arnold, London

Sugita S (1993) A model of pollen source area for an entire lake surface. Quat Res 39:239-244

Sugita S (1994) Pollen representation of vegetation in quaternary sediments: theory and method in patchy vegetation. $\mathrm{J}$ Ecol $82: 881-897$

Sugita S (2007a) Theory of quantitative reconstruction of vegetation. I: pollen from large lakes REVEALS regional vegetation composition. Holocene 17:229-241

Sugita S (2007b) Theory of quantitative reconstruction of vegetation. II: all you need is LOVE. Holocene 17:243-257

Sugita S, Gaillard M-J, Broström A (1999) Landscape openness and pollen records: a simulation approach. Holocene 9:409-421

Sugita S, Parshall T, Calcote R (2006) Detecting differences in vegetation among paired sites using pollen records. Holocene $16: 1,123-1,135$

Sugita S, Gaillard M-J, Hellman S, Broström A (2008) Model-based reconstruction of vegetation and landscape using fossil pollen. In: Posluschny A, Lambers K, Herzog I (eds) Layers of Perception, Proceedings of the 35th International Conference on Computer Applications and Quantitative Methods in Archaeology (Kolloquien zur Vor- und Frühgeschichte 10). Habelt, Bonn, pp 385-391

Sugita S, Parshall T, Calcote R, Walker K (2010) Testing the landscape reconstruction algorithm for spatially explicit reconstruction of vegetation in northern Michigan and Wisconsin. Quat Res 74:289-300

Sundbärg (1883) Dödligheten månads- och årstidsvis i Sverige, 1861-1880 (Monthly and seasonal variation in mortality in Sweden, 1861-80) (in Swedish). Statistisk Tidskrift 69:153-194

Thompson R, Bloemendal J, Dearing JA, Oldfield F, Rummery TA, Stober JC, Turner GM (1980) Environmental applications of magnetic measurements. Science 207:481-486

Wikman H (2000) Beskrivning till berggrundskartorna 5E Växjö NO och NV. Sveriges geologiska under-sökning Af $201 \& 216$

Willis KJ, Birks HJB (2006) What is Natural? The need for a longterm perspective in biodiversity conservation. Science 314 : $1,261-1,265$ 